\title{
First report of an alphasatellite associated with Okra enation leaf curl virus
}

\author{
S. A. Chandran · R. M. Packialakshmi • \\ K. Subhalakshmi · C. Prakash • K. Poovannan • \\ A. Nixon Prabu $\cdot$ P. Gopal $\cdot$ R. Usha
}

Received: 2 January 2013/Accepted: 1 March 2013/Published online: 10 March 2013

(C) Springer Science+Business Media New York 2013

\begin{abstract}
An alphasatellite DNA associated with Okra enation leaf curl virus (OELCuV) which causes enation and leaf curling in okra (Abelmoschus esculentus) plants was characterized. The full-length DNA comprises 1,350 nucleotides and shows typical genome organization of an alphasatellite. It shows the highest nucleotide sequence identity (79.7\%) to Hollyhock yellow vein virus-associated symptomless alphasatellite (HoYVSLA). This is the first report of the association of an alphasatellite with OELCuV from India.
\end{abstract}

Keywords Okra enation leaf curl virus · Begomovirus · Alphasatellite

\section{Introduction}

Begomoviruses in the family Geminiviridae are transmitted by the whitefly vector Bemisia tabaci. The geminate particles of begomoviruses encapsidate a small circular singlestranded DNA genome that can be either monopartite (DNA A) or bipartite (DNA A and DNA B). In some cases the monopartite begomoviruses are associated with additional single-stranded circular DNA components, which are half the size of DNA A namely betasatellite and/or alphasatellite [10]. Okra or bhendi (Abelmoschus esculentus) is cultivated in tropical, subtropical, and warm temperate

S. A. Chandran · R. M. Packialakshmi · P. Gopal · R. Usha ( $₫)$ Department of Plant Biotechnology, School of Biotechnology, Madurai Kamaraj University, Madurai 625021, India

e-mail: abayamba@gmail.com

K. Subhalakshmi - C. Prakash · K. Poovannan · A. Nixon Prabu RASI Seeds Pvt Ltd, Attur, India regions around the world. In Africa, the leaf curl diseases of okra are caused by a complex of begomoviruses consisting of Cotton leaf curl Gezira virus (CLCuGV), Okra yellow crinkle virus (OYCrV), and Hollyhock leaf crumple virus (HoLCrV), associated with Cotton leaf curl Gezira betasatellite (CLCuGB) and Cotton leaf curl Gezira alphasatellite (CLCuGA) [12]. In India, bhendi yellow vein mosaic disease is caused by Bhendi yellow vein mosaic virus associated with Bhendi yellow vein mosaic betasatellite [5]. Recently Venkataravanappa et al. [13] have reported the emergence of OELCuV associated with a betasatellite. In the present study we report the presence of a novel alphasatellite associated with OELCuV from Surat, India.

\section{Methodology}

Okra plants showing enation and leaf curling symptoms were collected from okra fields in Surat, India in 2011. A modified method of Chen and Ronald [2] was used for isolating total DNA from the infected okra plants exhibiting the symptoms.

Rolling circle amplification was performed using $\varphi 29$ DNA polymerase (Fermentas) on total DNA isolated from the diseased plants as template using the following protocol: $20-50 \mathrm{ng}$ of total DNA was mixed with $\varphi 29$ enzyme buffer, dNTPs (1 mM), and exo-resistant random hexamers $(50 \mu \mathrm{M})$ and denatured for $3 \mathrm{~min}$ at $95^{\circ} \mathrm{C}$, and then allowed to cool gradually to room temperature. Next, $0.02 \mathrm{U}$ of pyrophosphatase and 6-8 U of $\varphi 29$ DNA polymerase were added and incubated at $30{ }^{\circ} \mathrm{C}$ for $18-20 \mathrm{~h}$. Finally, the enzyme was inactivated by incubating at $65{ }^{\circ} \mathrm{C}$ for $10 \mathrm{~min}$. The RCA product was run on a $1 \%$ agarose gel to confirm amplification. 
Table 1 Alphasatellites used in the sequence analysis with their respective abbreviations and European nucleotide archive accession numbers

\begin{tabular}{|c|c|c|c|}
\hline $\begin{array}{l}\text { S. } \\
\text { no }\end{array}$ & Alphasatellite name & $\begin{array}{l}\text { Accession number } \\
\text { (ENA) }\end{array}$ & Abbreviation \\
\hline 1 & $\begin{array}{l}\text { Hollyhock yellow vein virus-associated symptomless alphasatellite, isolate [Pakistan:17-5:06] } \\
\text { Lahore2 }\end{array}$ & FR772086 & HoYVSLA \\
\hline 2 & Gossypium mustelinum symptomless alphasatellite [Gossypium lobatum] & FJ218496 & GMusSLA \\
\hline 3 & Gossypium davidsonii symptomless alphasatellite isolate Dav-alphaB-7 & EU384652 & GDavSLA \\
\hline 4 & Croton yellow vein mosaic alphasatellite & FN658709 & CroYVMA \\
\hline 5 & Vernonia yellow vein Fujian virus alphasatellite & JF733780 & VeYVFjA \\
\hline 6 & Cotton leaf curl Gezira alphasatellite, isolate BF:Po:Okra1 & FN554581 & CLCuGeA \\
\hline 7 & Okra yellow crinkle Cameroon alphasatellite [CM:Lys1sp3:09] & FN675285 & OYCrCMA \\
\hline 8 & Okra leaf curl disease-associated DNA 1 , isolate OBKG & FM164739 & OLCuA \\
\hline 9 & Sida yellow vein disease-associated DNA 1, isolate Y340 & FN806782 & SiYVA \\
\hline 10 & Tobacco curly shoot alphasatellite isolate WSFA1 & HQ407396 & TbCSA \\
\hline 11 & $\begin{array}{l}\text { Ageratum conyzoides-associated symptomless virus alphasatellite, isolate [Pakistan:17-5:06] } \\
\text { Lahore1 }\end{array}$ & FR772085 & AConSLA \\
\hline 12 & Papaya leaf curl alphasatellite isolate CLCuV & JQ322970 & $\mathrm{PaLCuA}$ \\
\hline
\end{tabular}

The high molecular weight $\varphi 29$ DNA polymerase rolling circle amplification product was digested with HindIII. Digestion was carried out for $3 \mathrm{~h}$ at $37^{\circ} \mathrm{C}$ with $5 \mathrm{U}$ of enzyme. The product was run on a $1 \%$ agarose gel, which showed the presence of $\sim 2.7$ and $\sim 1.4 \mathrm{~kb}$ digestion products which were gel eluted and cloned into $\mathrm{pBSIIKS}+$ vector digested with HindIII to create pBKS enation A DNA Surat and pBKS satellite DNA Surat, respectively. Both the clones were confirmed by restriction digestion and sequenced.

Sequencing results were assembled and analyzed using EMBOSS GUI [9]. The ORFs present in the DNA were predicted using the ORF finder program available at http://www.ncbi.nlm.nih.gov/projects/gorf/ and confirmed by similarity search using BLAST [1]. FASTA (http://www. ebi.ac.uk/) analysis [8] was used for selecting the related sequences (Table 1), which were used for multiple sequence alignment with ClustalX 2.1 [6] and subsequently the phylogenetic tree was constructed by neighbor-joining method [11] with bootstrap value [3] of 1,000 in order to determine the reliability of the trees.

\section{Results}

The complete nucleotide sequence of the clone pBKS enation A DNA Surat was identified as 2,741 nt (NCBIgenbank Okra KC342220). It shares the highest nucleotide sequence identity $(99.3 \%)$ to Okra enation leaf curl virus - [India:Munthal EL32:2006]. Based on the species demarcation threshold ( $<89 \%)$ for begomoviruses [4], it is an isolate of Okra enation leaf curl virus from Surat. The complete nucleotide sequence of the clone pBKS satellite DNA Surat was identified as 1,350 nt (ENA accession

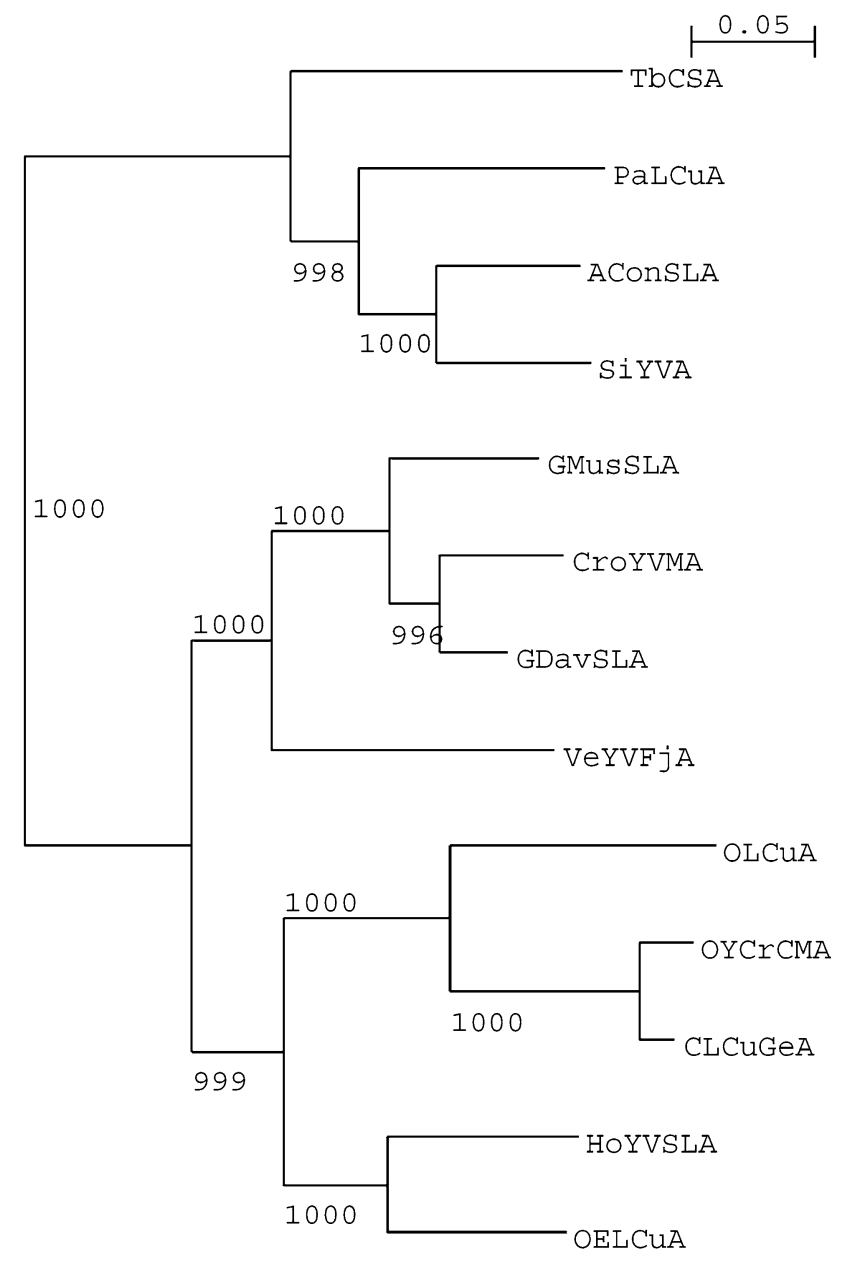

Fig. 1 Phylogenetic tree obtained using Neighbor-joining method in ClustalX2.1 with 1,000 bootstrap replications using complete nucleotide sequences of alphasatellites. Horizontal distances are proportional to calculated mutation distances and vertical distances are arbitrary. The bootstrap values are shown at the nodes 
number: HF546575). It shares the highest nucleotide identity $(79.7 \%)$ to HoYVSLA. The alphasatellite has been named as Alphasatellite associated with Okra enation leaf curl virus (OELCuA), based upon the proposed demarcation threshold (84\%) for distinct alphasatellites [7]. A phylogenetic tree was constructed (Fig. 1) and OELCuA was shown to be clustering with HoYVSLA and Okra leaf curl-associated DNA 1 (OLCuA).

This is the first report of association of an alphasatellite with OELCuV which causes enation and leaf curling in okra plants in India.

Acknowledgments We would like to thank Dr. V. Subramanian of RASI Seeds Pvt. Ltd for his support and the Department of Biotechnology, Government of India, for funding.

\section{References}

1. S. Altschul, W. Gish, W. Miller, E. Myers, D. Lipman, J. Mol. Biol. 215(3), 403-410 (1990)
2. D.H. Chen, P.C. Ronald, Plant Mol. Biol. Rep. 17, 53-57 (1999)

3. J. Dopazo, J. Mol. Evol. 38, 300-304 (1994)

4. C.M. Fauquet, R.W. Briddon, J.K. Brown, E. Moriones, J. Stanley, M. Zerbini, X. Zhou, Arch. Virol. 153, 783-821 (2008)

5. J. Jose, R. Usha, Virology 317, 310-317 (2003)

6. M.A. Larkin, G. Blackshields, N.P. Brown, R. Chenna, P.A. McGettigan, H. McWilliam, F. Valentin, I.M. Wallace, A. Wilm, R. Lopez, J.D. Thompson, T.J. Gibson, D.G. Higgins, Bioinformatics 23, 2947-2948 (2007)

7. M.S. Nawaz-ul-Rehman, R.W. Briddon, C.M. Fauquet, PLoS ONE 7(8), e40050 (2012). doi:10.1371/journal.pone.0040050

8. W. Pearson, Current protocols in bioinformatics. 8, 3.9.1-3.9.23 (2004)

9. P. Rice, I. Longden, A. Bleasby, Trends Genet. 16(6), 276-277 (2000)

10. M.R. Rojas, C. Hagen, W.J. Lucas, R.L. Gilbertson, Annu. Rev. Phytopathol. 43, 361-394 (2005)

11. N. Saitou, M. Nei, Mol. Biol. Evol. 4, 406-425 (1987)

12. F. Tiendrébéogo, P. Lefeuvre, M. Hoareau, J. Villemot, G. Konaté, A.S. Traoré, N. Barro, V.S. Traoré, B. Reynaud, O. Traoré, J.M. Lett, Virol J 7, 48 (2010)

13. V. Venkataravanappa, C.N.L. Reddy, P. Swaranalatha, S. Jalali, R.W. Briddon, M.K. Reddy, Virol J 8, 555 (2011) 